\author{
KENESHBEK YRYSOV ${ }^{1,2}$, MITALIP MAMYTOV ${ }^{2}$, \\ ELIZA ALIK KYZY3 (Bishkek, Kyrgyz Republic)
}

\title{
DIAGNOSTIC VALUE OF OPHTHALMOLOGICAL INVESTIGATION IN PATIENTS WITH BRAIN TUMORS
}

\author{
${ }^{1}$ Nagoya University Graduate School of Medicine, Young Leader's Program (Nagoya, Japan); \\ ${ }^{2}$ Kyrgyz State Medical Academy n. a. I. K. Akhunbaev (Bishkek, Kyrgyz Republic); ${ }^{3}$ National \\ Hospital of the Kyrgyz Republic, Eye Microsurgery Department \#2 (Bishkek, Kyrgyz Republic) \\ $<$ keneshbek.yrysov@gmail.com>
}

\begin{abstract}
The objective of the work was an accentuation of clinical appearances of pathogenesis of congestive optic disc as a basis for improving their diagnosis. Material and methods. This work based on the analysis of ophthalmological symptoms in 169 patients with brain tumors that underwent neurosurgical tumor surgery at Neurosurgical Clinic of National Hospital (Ministry of Health of the Kyrgyz Republic) from 2014 to 2019. Patient's age varied from 14 years to 67 years old, medium age was 34 years. The number of male was 63, and the number of female was 106. All patients were examined by using neurological investigation, MRI of the brain before surgery and MRI/CT after surgery. Benign tumors have been identified in 56 patients and malignant tumors in 50 patients. Glial brain tumors identified in most cases (49 patients). Results. We could investigate visual function of 55 (93\%) patients out of 169 patients with congestive optic disc caused by large appearances in the brain. 46 (27.4\%) of patients out of 169 had reduced visual acuity caused by congestive optic disc. Meanwhile 22 (13.1\%) patients had acuity in both eyes by 1.0; 6 (3.3 \%) patients had a blind or a partially blind eye, whereas the reduction of visual acuity was in another eye; additionally 7 (4\%) patients were blind or nearly blind in both eyes. Conclusion. The frequency and severity of visual disorders in congestive optic disc depend on the congestive optic disc stages. The stage of severe congestive optic disc and other already existing visual disorders are prognostically unfavorable for visual functions of patients with congestive optic disc. The terms of congestive optic disc regression depend on the methods of treatment. Congestive optic disc regression is occurring slowly (from 1 month to 3 years) when the medicamental therapy is used for patients with benign intracranial hypertension. Surgical or bypass removal of the large appearance of liquor system of congestive optic disc regression is much faster (1 to 1.5 months).
\end{abstract}

Key words: Brain tumors; ocular fundus; congestive optic disc; ophthalmology; diagnostics; surgical management.

Introduction. For last decades the development of modern methods of neuroimaging and microsurgical techniques allowed to improve identification of large appearances in the brain for surgical treatment. However, studies of the dynamics of visual and oculomotor function after surgical treatment of patients with this disease are very few and are usually descriptive [7].

One of the frequent large appearances of the brain is neuro-ophthalmological challenge occurring as oculomotor and pupillary disorders and as appearances of intracranial hypertension in an ocular fundus. Consequently, it is recommended to evaluate the indications for surgical treatment of large appearances of the brain and its results by taking account the dynamics of neuro-ophthalmological symptoms in the postoperative period [2]. In nowadays' literature there are no data on instrumental investigation of severity of oculomotor disorders and their dynamics after removal of large lesions of the brain. Solving such issues, as determining the oculo- 
motor disorders in patients with large appearances in the brain, evaluation of their dynamics in early and late postoperative period will contribute to diagnosticate the oculomotor disorders on time, to implement proper evaluation of the results of treatment and to identify characteristics of recurrence of disease [8]. In modern literature it is emphasized that the pathogenesis of congestive optic disc (COD) is not completely clear. So there are unsolved questions listed below:

1) what features of structure of the optic nerve cause the development of COD?

2) whether papilledema is limited or is extend to the orbital part of its trunk?

3) in which segment of optic nerve primarily affects the nerve fibers and starts developing the process of atrophy in COD?

Many previously proposed theories of COD pathogenesis based on pathological data, which frequently contradict each other. The improvement of such research methods as laser retinal tomography, MRT, ultrasound scan, automatic static perimetry gives possibilities to implement the intravital study of anatomical structure peculiarities of the optic nerve in COD and to identify functional disorders of optic nerve at an earlier stage [9].

The works on studying patients with COD with the help of laser retinal tomography, MRT and ultrasound scan are few and they are rare in current literature. There are some publications devoted to study of optic nerve in COD using modern imaging techniques. However, the results of study are not compared with the data of the clinic [4]. Meanwhile, these studies are topical in present day as they provide new opportunities for the study of individual pathogenesis and laws of clinical processes in COD. In addition, the studies allow to improve the diagnosis and to clarify patient surveillance with COD [1].

The objective of the work was an accentuation of clinical appearances of pathogenesis of congestive optic disc as a basis for improving their diagnosis.

Materials and methods. Study population. This work based on the analysis of neuro-ophthalmological symptoms in 169 patients with brain tumors underwent neurosurgical tumor removal at Neurosurgical Clinic of National Hospital (Ministry of Health of the Kyrgyz Republic) from 2014 to 2019 (table). Benign tumors were found in 56 patients, malignant - in 50 patients. The largest number of glial tumors was found in 49 patients.

General characteristics of series

\begin{tabular}{|l|c|c|}
\hline \multicolumn{1}{|c|}{ Data } & Number (\%) & P value \\
\hline Number of series & $169(100 \%)$ & 0.375 \\
\hline Men & $63(37.3 \%)$ & 0.236 \\
\hline Women & $106(62.7 \%)$ & 0.302 \\
\hline Tumor resection & $140(82.8 \%)$ & 0.284 \\
\hline Total & $29(17.2 \%)$ & \\
\hline Subtotal & & 0.228 \\
\hline Visual function & $46(27.4 \%)$ & 0.203 \\
\hline Reduced vision & $22(13.1 \%)$ & 0.193 \\
\hline Blindness & & 0.205 \\
\hline Hemianopia & $41(35.7 \%)$ & 0.285 \\
\hline Homonymous & $13(7.7 \%)$ & \\
\hline Binasal & $15(8.9 \%)$ & \\
\hline Bitemporal & & \\
\hline Secondary atrophy & $6 \%$ & \\
\hline Initial COD & $12.1 \%$ & \\
\hline Moderate COD & $39.3 \%$ & \\
\hline Severe COD & & \\
\hline
\end{tabular}


All patients underwent neurological examination, MRI of the brain before surgery, MRI/CT of the brain after surgery. The age of patients ranged from 14 to 67 , the medium age was $34.00 \pm 5.27$. The number of males was $63(37.3 \%)$ and the female was $106(62.7 \%)$.

Data collection and analysis. Neurosurgeons conducted neurosurgical removal of brain tumors for all patients in the Clinic of Neurosurgery of the National Hospital. The total removal of brain tumors was implemented for most of patients (in $140-82.8 \%$ cases) and subtotal removal (in 29 - $17.2 \%$ cases). Dynamic observation in the late postoperative period was conducted in 68 patients in a period of 1.5 months to 5 years, 57 patients out of 68 were examined with large brain tumors. In the early postoperative period 168 patients were examined.

We estimated both eye (visual function) and movement of the eyeballs. Clinical evaluation of oculomotor disorders is carried on a scale from 0 to 6 . The evaluation of 0 (zero) is for no sight or movement of the eyeball. We gave 1 point for limitation of sight or movement of the eyeball that was no more than $1 \mathrm{~mm}$ from the norm; $1 / 3 \mathrm{~mm}$ from the norm was 2 points, $1 / 2 \mathrm{~mm}$ from the norm was 3 points, $2 / 3$ from the norm -4 points, no random sight or movement of the eyeball -5 points; no reflex sight -6 points.

Results and methods. Visual function of patients with brain tumors. We could investigate visual function of 55 patients $(93 \%)$ out of 169 patients with COD caused by large appearances in the brain. $46(27.4 \%)$ of patients out of 169 had reduced visual acuity caused by COD. Meanwhile $22(13.1 \%)$ patients had acuity in both eyes by $1.0 ; 6(3.3 \%)$ patients had a blind or a partially blind eye, whereas the reduction of visual acuity was in another eye; additionally, 7 (4\%) patients were blind or nearly blind in both eyes.

It is should be emphasized there were difficulties in examining visual field of some patients with tumor in the brain. But other patients could ignore such visual field defects as an extension of blind spot or central scotoma.

We investigated visual field of 115 patients accurately. 52 patients of them had no changes in visual field. 2 patients had a normal visual field in only one eye, whereas another eye was not identified due to reduction eye acuity. But the reduction of acuity is not associated with COD. It was clarified that $41(35.7 \%)$ patients had changes in visual field of the type of homonymous hemianopsia, showing the affection of large appearance in the central neuron of optic tract without any signs of optic nerve lesions (figure).

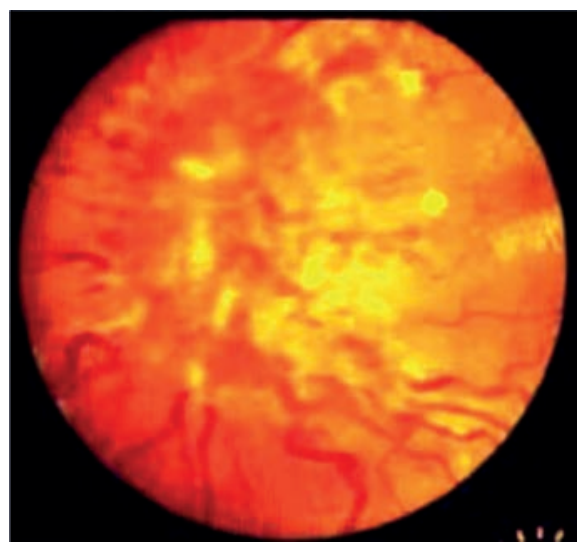

Ophthalmoscopy: congestive optic disc in patient with supratentorial brain tumor

The changes in the visual field due to the presence of COD were in 89 patients, that is $53 \%$ of all significantly examined patients. There were minimum changes (46 patients $27.2 \%$ ) in visual field causing by only an extension of the blind spot in one or both eyes. It is also detected the narrowing in the nasal visual field at one or both eyes (13 patients $-7.7 \%$ ), concentric narrowing (15 patients $-8.9 \%$ ), severe narrowing of visual field with central vision abnormality and the preservation of a small area in the temporal part (2 patients $-1.4 \%$ ). Moreover, 10 $(5.9 \%)$ patients had a combination of these mentioned visual field defects.

Along with the typical COD disorders in the visual field, hemianoptic defects were observed in patients with large appearances in the brain, combined with well seen part of visual field narrowing 
( 3 patients $-1.9 \%$ ). The presence of these changes in visual field indicated the involvement not only of the central neuron of optic tract, but optic nerve, as well.

The frequency and severity of visual disorders depended on the stage of COD. Thus, patients' visual acuity with COD incipience was 1.0, that is the visual acuity was $99.5 \%$; visual acuity with moderately severe of COD was $12.5 \%$, visual acuity was equal to 1.0 , the visual acuity with severe COD was $34.5 \%$ visual acuity was equal to the tenth, and 4,7\% of the eyes were blind or nearly blind. $62.7 \%$ of eyes were almost blind or blind during investigation of fundus of secondary atrophy.

In the analysis of visual field more defects were observed in severe COD and in ophthalmoscopic image of secondary atrophy of the optic disc:

- $6 \%$ of eyes werein patients with initial COD;

- $12.1 \%$ of eyes were in patients with moderately severe of COD;

- $39.3 \%$ of eyes were in patients with severe COD;

- $93.3 \%$ of eyes were in patients according to ophthalmoscopic picture of secondary atrophy.

Disorders of central vision were detected only in patients with severe COD and ophthalmoscopic image of secondary atrophy. The appearances of defects in visual field advanced the reduction of visual acuity. Patients with low visual acuity had big changes in visual field.

Discussion. Brain tumors commonly reason for progressive visual disorders and visual field loss (up to $95 \%$ ) terminated weeks to months previously the diagnosis [2]. Early symptoms and signs are frequently misjudged both by the patients and doctors, and suitable surveys are accordingly postponed [4, 8].

There are three most common natures of brain tumors in adults such a pituitary adenoma, meningioma, and craniopharyngioma, in diminishing direction of incidence $[1,9]$. Clinical feature is linked with anatomic site of the chiasm. Cranial nerve palsy and double-vision can advance of parasellar extension of the neoplasm [10]. In this study, neuro-ophthalmologic investigation and neuro-imaging verified benign tumors in 56 patients, malignant - in 50 patients; the largest number of glial tumors was found in 49 patients; all cases were admitted due to visual disorders or visual field defects.

Olfactory groove meningiomas most frequently manifest with symptoms of headache, anosmia, and personality alterations [11]. Additionally, they can range to a gigantic extent without presenting any symptom and be simply disordered with toxic optic neuropathy, particularly in patients who manifest with bilateral vision loss and visual field deficiencies. M. J. Puchner et al. [9] advocated that the generally very late diagnosis of meningiomas as a reason of visual loss may be recognized to the low occurrence of the tumor.

In conclusion, the ophthalmologist may be the first doctor to meet a patient with clinical appearances of brain tumors that may result in neurologic and ocular problems. Neuro-ophthalmological symptoms should be prudently considered to escape a delay in the diagnosis of brain tumors. The probability of brain tumors have to be considered in the etiology of visual disorders in advance getting a conclusive diagnosis.

Conclusion and discussion. It was found that visual disorders at COD are identical with different neurosurgical pathology and caused by development of atrophy of the optic nerve, edema and focal changes in the central area of retina.

The nature of visual disorders in COD showed primarily lesions of the optic nerve fibers, extending from the peripheral parts of the retina. Disorders of visual field advanced the reduced visual acuity with COD.

The frequency and severity of visual disorders in COD depend on the COD stages. The stage of severe COD and other already existing visual disorders are prognostically unfavorable for visual functions of patients with COD. 
The terms of COD regression depend on the methods of treatment. COD regression is occurring slowly (from 1 month to 3 years) when the medicamental therapy is used for patients with benign intracranial hypertension. Surgical or bypass removal of the large appearance of liquor system of COD regression is much faster (1 to 1.5 months).

High-resolution of MRT allows studying anatomy x-ray of orbital segment, to detect the extension of intrathecal area and the change of the orbital part of trunk of the optic nerve at its various intervals. The parameters of the optic nerve, identified in MRT, depend on the stage of COD.

Acknowledgements. Authors were permitted to use the data of patients of $\mathrm{Na}-$ tional Hospital (Ministry of Public Health of Kyrgyz Republic) to conduct research and to publish their results in any scientific journals.

Conflict of interests. There is no conflict of interests to disclose for each author.

$$
\text { Ref erences }
$$

1. Aui-aree N., Phruanchroen C., Oearsakul T. et al. Three years experience of suprasellar tumors in neuro-ophthalmology clinic // Med. Assoc. Thai. - 2010. - Vol. 93, N 7. - P. $818-$ 823.

2. Bouyon M., Blanc F., Ballonzoli L. et al. Optic neuropathy and meningioma: a diagnostic trap // J. Fr. Ophthalmol. - 2013. - Vol. 36, N 3. - P. 221-229.

3. Harbert M. J., Yeh-Nayre L. A., O'Halloran H. S. et al. Unrecognized visual field deficits in children with primary central nervous system brain tumors // J. Neurooncol. - 2012. Vol. 107, N 3. - P. 545-549.

4. Jung J. J., Warren F. A., Kahanowicz R. Bilateral visual loss due to a giant olfactory meningioma // Clin. Ophthalmology. - 2012. - Vol. 6. - P. 339-342.

5. Kitthaweesin K., Ployprasith C. Ocular manifestations of suprasellar tumors // J. Med. Assoc. Thai. - 2008. - Vol. 91, N 5. - P. 711-715.

6. Margalit N., Barkay G., Kesler A. Delay in diagnosis of meningiomas involving the optic apparatus: conclusions and guidelines for early imaging based on our experience in 100 patients // Harefuah. - 2013. - Vol. 152, N 3. - P. 135-138.

7. Masaya-anon P., Lorpattanakasem J. Intracranial tumors affecting visual system: 5-year review in Prasat Neurological Institute // J. Med. Assoc. Thai. - 2008. - Vol. 91, N 4. - P. 515519.

8. Moss H. E., Liu G. T. Acute optic neuropathy associated with an intracranial mass in a patient with POEMS syndrome // J. Neuroophthalmol. - 2012. - Vol. 32, N 1. - P. $45-47$.

9. Puchner M. J., Fischer-Lampsatis R. C., Herrmann H. D., Freckmann N. Suprasellar meningioma. A disease still frequently diagnosed too late // Dtsch. Med. Wochenschr. - 1998. Vol. 123, N 34-35. - P. 991-996.

10. Snyder W. E., Shah M. V., Weisberger E. C., Campbell R. L. Presentation and patterns of late recurrence of olfactory groove meningiomas // Skull. Base Surg. - 2000. - Vol. 10, N 3. P. 131-139.

11. Valassi E., Biler B. M. K., Klibanski A., Swearingen B. Clinical features of non-pituitary sellar lesions in a large surgical series // Clin. Endocrinol. (Oxf). - 2010. - Vol. 73, N 6. P. 798-807.

\section{ДИАГНОСТИЧЕСКОЕ ЗНАЧЕНИЕ \\ ОФТАЛЬМОЛОГИЧЕСКОГО ИССЛЕДОВАНИЯ \\ У БОЛЬНЫХ С ОПУХОЛЬЮ ГОЛОВНОГО МОЗГА}

К. Б. Брыссов, М. М. Мамылтов,

Э. Алик кызы (Бишкек, Кирги́зская Респу́блика)

Цель работы - определить клинические проявления отдельных звеньев патогенеза застойного диска зрительного нерва для основы совершенствования их диагностики. Материал и методы. Работа основана на анализе нейроофтальмологической симптоматики у 169 больных с объёмным образованием в головном мозге, оперированных в клинике нейрохирургии Национального госпиталя Минздрава Киргизской Республики с 2014 по 
2019 гг. Возраст пациентов - 14-67 лет, средний возраст - 34 года. Лиц мужского пола было 63, женского - 106. Всем пациентам проводилось неврологическое обследование, МРТ головного мозга до операции, МРТ/КТ головного мозга после операции. Доброкачественная опухоль была выявлена у 56 больных, злокачественная - у 50 больных. Наибольшее количество составили опухоли глиального происхождения (49 больных). Результаты и их обсуждение. Из 169 больных с застойным диском зрительного нерва, обусловленного наличием объёмного образования в головном мозге, зрительные функции удалось исследовать у 55 пациента (93 \%). Снижение остроты зрения, обусловленное наличием застойного диска зрительного нерва, было выявлено у 46 (27,4 \%). У 22 (13,1\%) больных острота зрения на оба глаза равнялась 0,1 , у 6 (3,3\%) слепым или практически слепым был один глаз, при сниженной остроте зрения на другом глазу, 7 (4 \%) больных были слепыми или практически слепыми на оба глаза. Заключение. Частота и степень выраженности зрительных нарушений при застойном диске зрительного нерва зависят от стадии застоя. Прогностически неблагоприятным для зрительной функции у пациентов с застойным диском зрительного нерва являются стадия застоя и наличие в анамнезе зрительных нарушений. Срок регрессии застоя дисков зрительных нервов зависит от метода лечения: при медикаментозной терапии у пациентов с доброкачественной внутричерепной гипертензией регресс застойных дисков зрительных нервов происходит медленно (от 1 мес до 3 лет), при хирургическом удалении объёмного образования или шунтировании ликворной системы регресс застоя дисков зрительных нервов происходит значительно быстрее (от 1 до 1,5 мес).

Ключевые слова: опухоли головного мозга; глазное дно; застойный диск зрительного нерва; офтальмология; диагностика; хирургическое лечение.

\section{ДІАГНОСТИЧНЕ ЗНАЧЕННЯ \\ ОФТАЛЬМОЛОГІЧНОГО ДОСЛІДЖЕННЯ \\ У ХВОРИХ 3 ПУХЛИНАМИ ГОЛОВНОГО МОЗКУ}

\section{К. Б. Ирисов, М. М. Мамитов, \\ Э. Алик кизи (Бішкек, Кіргізська Республіка)}

Мета. Виділення клінічних проявів окремих ланок патогенезу застійного диска зорового нерва як основи вдосконалення їх діагностики. Матеріали і методи. Робота грунтована на аналізі нейроофтальмологічної симптоматики у 169 хворих з об'ємним утворенням головного мозку, оперованих в клініці нейрохірургії національного госпіталю мінохоронздоров'я Кіргізской Республіки з 2014 по 2019 рік. Вік пацієнтів - 14-67 років, сердний вік - 34 роки. Чоловіків було 63, жінок - 106. Усім пацієнтам проводилося неврологічне обстеження, МРТ головного мозку до операції, МРТ/КТ головного мозку після операції. Доброякісні пухлини були виявлені у 56 хворих, злоякісні - у 50. Найбільшу кількість склали пухлини гліального ряду (49 хворих). Результати та іх обговорення. 3 169 хворих із застійним диском зорового нерву, обумовленим наявністю об'ємного утворення головного мозку, зорові функції вдалося досліджувати у 55 пацієнтів (93 \%). Зниження гостроти зору, обумовлене наявністю застійного диску зорового нерву було виявлене нами у $46(27,4 \%)$ хворих. У $22(13,1 \%)$ пацієнтів гострота зору на обидва очі рівнялася 0,1 ; у $6(3,3 \%)$ сліпим або практично сліпим було одне око зі зніженням гостроти зору на іншому оці; 7 (4 \%) пацієнтів були сліпими або практично сліпими на обидва ока. Висновок. Частота і міра вираженості зорових порушень при застійном диске зорових нервів залежать від стадії застою дисків зорових нервів. Прогностично несприятливими для зорових функцій у пацієнтів із застійними дисками зорових нервів являються стадія виражених застійних дисків зорових нервів і наявність зорових порушень. Терміни регресу застою дисків зорових нервів залежать від методів лікування: при медикаментозній терапії у пацієнтів 3 доброякісною внутрішньочерепною гіпертензією регрес застійних дисків зорових нервів відбувається повільно (від 1 міс до 3 років), при хірургічному видаленні об'ємного утворення або шунтуючої операції на лікворній системі регрес застою дисків зорових нервів відбувається значно швидше (від 1 до 1,5 міс).

Ключові слова: пухлина головного мозку; очне дно; застійний диск зорового нерву; офтальмологія; діагностика; хірургічне лікування. 